\title{
Challenges and Future Trends for Thai Education: Conceptual Frameworks into Action
}

\author{
https://doi.org/10.3991/ijep.v9i2.10220 \\ Panarit Sethakul ${ }^{(\varpi)}$, Nattakant Utakrit \\ King Mongkut's University of Technology Bangkok, Bangkok, Thailand \\ panarit.s@fte.kmutnb.ac.th
}

\begin{abstract}
Engineering and technological changes are accelerating today at an unprecedented period and speed, triggering a revolution in engineering education. This short research aims to analyze, synthesize the literature and discuss the challenges and future trends toward Industry Revolution 4., Thailand 4.0, and Education 4.0 agendas based on a documentary research method. The authors reviewed the literature that was relevant to the three agendas from various resources. Astonishingly, the significant finding reflects the fact that educational institutions need to seize on the opportunity to train and educate a young generation of creative, flexible and hands-on engineers and technical educators to work collaboratively with others in an international setting.
\end{abstract}

Keywords-Industry Revolution 4.0, Thailand 4.0, and Education 4.0

\section{$1 \quad$ Introduction}

The uttering of rapid economic and social change with the advancement of science and technology has adapted to basic education provision to harmonize with such change and progress. Innovation and practical strategies must be identified to improve the quality of education. Learner's capacities for competitiveness and creative cooperation will strengthen Thailand's international competitive position. There are also urgent needs for the inculcation of awareness of Thainess on self-discipline, concern for public interest and adherence to a democratic form of government under the constitutional monarchy as stipulated in Section 80 of the Constitution of the Kingdom of Thailand 2007 and the National Education Act 1999 and Amendments 2002 [1]. The Office of Education Council proposes a development paradigm shift in the education of Thailand 4.0 toward the $21^{\text {st }}$ century. The government's national innovation-driven development strategy, the primary focus of a new 20-year plan, announced in the National Scheme of Education B.E. 2560-2579 (2017-2036) [2] provides a national capacity building framework into action, regarding educational management, educational opportunity, educational quality, instructional effectiveness, the administration of educational institutions, budget management, and educational development in the competitive era. The 20 -year national strategy is crucial for Thailand. The plan is developed under the principle of Sufficiency Philosophy, which is consistent with the United Nations' Sustainable Development Goals. The vision of the stability, prosperi- 
ty, sustainability consists of six areas, which include security, competitiveness enhancement, human resource development, social equality, green growth, and rebalancing and public sector development [3]. The national strategic plan can achieve sustainable development and have a clear direction for long-term development by building strength within the nation and connecting the country to the global community.

\section{Thailand Education System}

In Thailand, education is considered a fundamental factor in human resources development and a mechanism for developing the Thai economy and society. Education in Thailand has a long history reflecting the evolution of teaching and learning in the country and has gone through several major reforms for greater access to the education of people. The education system in Thailand is similar to the K-12 system in the United States. The program starts as earliest as a pre-school to as highest as a doctoral degree and possible extensions to postdoctoral study for individual preference (see Figure 1).

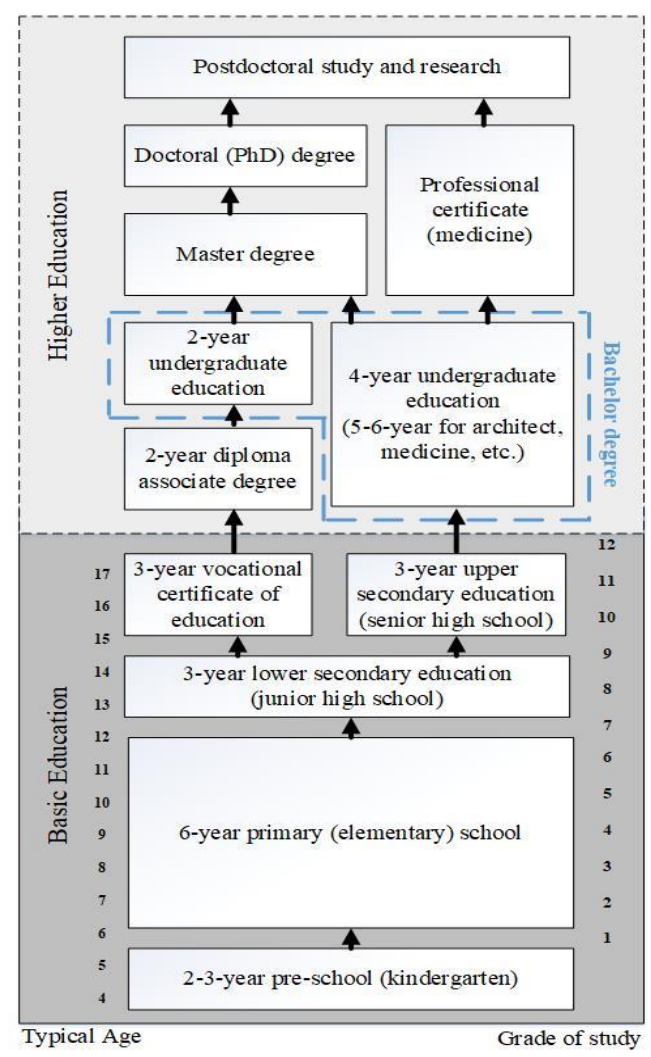

Fig. 1. Thai education system 
Thailand's Ministry of Education announced mandatory education from primary school to grade $9[4,5]$. Free tuition is also offered to children from pre-school to grade 12. Typically, studies at the tertiary level can take a varying number of years to complete depending on the field of study. Within the higher education system, the first professional qualification is that of the bachelor's degree, which can be obtained after four years of tertiary study [6]. Five years of study are required in the fields of Architecture, Painting, Sculpture, Graphic Arts, while six years of study are necessary for Medicine, Dentistry, Veterinary Science, and Pharmacy [2]. After completing five or six years of study, graduates can immediately continue with a master's and then a doctoral degree like the graduates of four-year courses. Medical graduation can continue with a master's and a $\mathrm{PhD}$ in medical science study or a professional doctoral degree for physicians and surgeons. Some doctors might choose to pursue a Diploma of the (subspecialty) Board [7] of particular major field to study for some years, and the subsequent certificate of qualification that is awarded is equivalent to a $\mathrm{PhD}$ [8]. Within the framework and conceptual design of education, two proposed strategies that are important and relevant to the $21^{\text {st }}$ century skills are strategy 2 and 3. Strategy 2 is the development of research and the innovation of the workforce to enhance national competitiveness. The main aims include developing skills and capabilities relevant to the job market and national development, excellent and specialized graduates supported by the academic institutions, and knowledge and innovation constructed by research and development to add economic value. The objectives of this research were to study the current situation of 4.0 agendas and to study the trends of future research in Thailand.

\section{$3 \quad$ Methodology}

This research conducted a documentary research method to synthesize challenges and future trends among Industrial Revolutions 4.0, Thailand 4.0, and Education 4.0. Documentary research involves the use of texts, documents, and all forms of products as source materials, such as government publications, newspapers, innumerable other written, surveys and ethnography [9]. The source material for this study was obtained from government documentation, research, and online publications. The data obtained were classified under the three agendas. Each agenda explained and discussed the background and the changes in its direction toward the $21^{\text {st }}$ century. The results and conclusion were discussed in the following sections.

\section{$4 \quad$ Results and Discussion}

\subsection{Industrial revolution 4.0}

Technical advances change the way humans live and produce things. The giant leap in the growth of information and communication technology significantly affects the free flow of trade and information and beyond frontier markets [3]. The current 
production technology is entirely different from the past. The Industrial Revolution (IR) is the process of change from an agrarian and handicraft economy to one dominated by industry and machine manufacturing [7] and until the embed technology. Industry 1.0 started during the $1800 \mathrm{~s}$. This was the era of water- and steam-powered machines. As production capabilities increased, a business also grew from individual cottage owners to hire more employees to serve customers. Industry 2.0 began in the $20^{\text {th }}$ century. It is a production time for electricity to use as a source of power to supply individual machines. Industry 3 came after in the last few decades of the $20^{\text {th }}$ century. The period was the invention and manufacture of electronic devices, such as the transistor and, later, an integrated circuit chip. It was enabled the machine to fully automated operation and replaced labor work. Pressure to reduce costs caused manufacturers to relocate component and assembly operations to the lower cost countries. The digital revolution in the $21^{\text {st }}$ century leads to the fourth industrial revolution. Industry 4.0 is a current trend of business automation and digitalization of industries. It connects the internet of things (IOT) and embeds technology onto electronic devices with manufacturing techniques to enable systems to share information, analyze and use it conveniently. It also incorporates cutting-edge technologies including additive manufacturing, robotics, artificial intelligence, big data and data mining, other cognitive technologies, advanced materials, and augmented reality. The fourth industrial revolution impacts all aspects of human lives, occupations, and industry.

\subsection{Thailand 4.0}

It is unavoidable that Thailand has to embrace the significant changes coming on all forefronts, as promoted by the global IR 4.0 and national scheme on the revolution of Thailand 4.0. The revolution of Thailand 4.0 has strengthened the local industries, which are embedded in Thai society, to strive for stability, wealth, sufficient, sustainability, and synergy with the civil state framework. Thailand's 4.0 economic policy is a mindset, and the stakes have never been higher. The engineers can integrate artificial intelligence, data science, and information communication technology at work. This revolution can improve and uplift their names and reputation to reach the national benchmark and global career exposure. From the government perspective, the past three iterations of Thailand evolution were as follows [10]:

- Thailand 1.0 is an agrarian society that relied on the agricultural industry.

- Thailand 2.0 is the light industry such as textiles.

- Thailand 3.0 emphasizes on advanced industry or heavy industry and exports.

According to Wittayasin [11] the first period of economic model in Thailand 1.0 which was concerned about agriculture. Thai people mainly generated their income by farmland and livestock. The second stage is Thailand 2.0. As an outcome of the industrialization, it is about light industries with low labor cost such as garments and food processing. During this stage, tools were used in most economic activities. The country started many light industries, which emphasized domestic manufactures to serve the local needs. This model developed the country's economy from the lowincome to middle-income nation. Thailand 3.0 is the present economy of Thailand. As 
a result of the globalization, this third model is currently more relying on foreign technologies and focusing on heavy industries and exports. Thailand 4.0 focuses on a valued-based economy. There are three elements to be focused on. The first element aims to enhance the country and shift from a middle-income to a high-income nation through development using a knowledge-based economy, with an emphasis on research and development in science and technology, development of creative thinking and innovation. In the second element, Thailand will drive toward an inclusive society with equitable access to the fruits of prosperity and development. For the third element, it focuses on sustainable growth and development to achieve economic growth and sustainable development without destroying the environment. In order to achieve Thailand 4.0, the three goals are significantly concerned [4]:

- Thailand's transition from middle income to high income status

- A more inclusive society where all enjoy the fruits of prosperity and development.

- Sustainable economic growth without destroying the environment.

According to the Thai Embassy website in Washington, D.C., Thailand 4.0 can overcome traps by the following actions [3]:

- Building economic prosperity through innovation, knowledge, technology, and creativity. This creates a competitive growth engine to unlock individuals from the middle-income trap.

- Building social security through the equitable distribution of income, opportunity, and wealth operating under a principle of moving forward together without leaving anyone behind to unlock Thai citizens from the inequality trap.

- Creating sustainability through environmentally friendly development (green growth engine), to unlock Thai citizens from an imbalance trap.

Thailand 4.0 is the latest of Thailand's economic proposition that aims to adjust economic structure toward a value-based economy to step over a middle-class country trap. The fourth revolution transforms from traditional agriculture to new era agriculture which emphasizes on technology management in order to turn traditional small and medium enterprise (SME) with high capacity, low-value traditional services to achieve high-value, and low skilled labor to knowledgeable, specialized and highly skilled labor. Besides, the success will not only make the overall of Thailand economy set free from the middle-class country trap, but it can also reduce the dependence of foreign countries, and create economic and social balance to achieve real stability, prosperity, and sustainability [12]. The technology-supported teaching and learning process impact the educational sector. Education provision in Thailand needs to be improved in order to prepare learners for participation in the global economic system of this century, and for developing the country with highly competitive skills. Learning skills of the $21^{\text {st }}$ century; deemed a strategic guideline for learning management emphasizing on a body of knowledge, skills, expertise, and competency of learners, for daily living in a changing world. These challenges, both inside and outside the country have a significant impact on both the policies and practices of the provision of education services. Educational policies and practices need to be revised or de- 
signed to prepare Thais with skills and competencies corresponding to the realities of the 21 st century [3].

\subsection{Education 4.0}

The development of education has four following stages [13]:

- Centuries of experience with memorization

- Internet-enabled learning

- Consuming and producing knowledge

- Empowering education to produce innovation.

Education 1.0 was established to the need of the agricultural society. The knowledge is transferred from teacher to learner, using the concepts and a comprehensive study. The learner listened to the teacher on explanation as for the primary teaching and learning method.

Education 2.0 supported the requirement of industrial society with the concept of teaching to learn. The learning management focused on technology, which is to use as a tool at work.

Education 3.0 fulfilled the need for technological society by creating knowledge to self-learning. The learners are encouraged to focus on interactive learning between peers and teachers. The third revolution included all forms of materials, digital media, and social media as teaching and learning tools. The current education 4.0 caters to the need of the society in the innovative era. This learning develops the learner's ability to apply the new technology, which will help he or she to stay updated according to the changes in society. Education 1.0 was during ancient to middle ages; equation was imparted on a person-to-person basis. Education 2.0 allowed the masses to get access to basic education and brought in a culture of scientific inquiry. Education 3.0 was the emerging of the Internet, and IT changed the mode of delivery, providing a technology platform to learn. The role of a teacher has changed from that of an instructor to a facilitator, and technology has become omnipresent for content delivery in various online and distance learning programs. Education 4.0 puts the learner at the corner of the ecosystem and empowers him or her to structure individual paths keeping in mind the outcome.

Education 4.0 the learner will always be at the center of the education ecosystem, learning at the university as also from peers, industry, and society at large [14]. To respond on the global change, the new Ministry of Higher Education, Research and Innovations has been proposed with an emphasis on cooperation between the private and government sectors and civil society in to support innovations and budgeting system to the research field [15]. All levels of academic institutions in Thailand are eager and expedited to reform their curriculums and quality management. 


\subsection{Discussions}

The challenges and future trends in Thailand in the $21^{\text {st }}$ century are considered from several factors. There are issues toward challenges and trends in higher education, science, and research and innovation reform as summarized in Table 1.

Table 1. Issues toward challenges and trends in education

\begin{tabular}{|l|l|l|}
\hline \multicolumn{1}{|c|}{ Issues } & \multicolumn{1}{|c|}{ Past } & \multicolumn{1}{c|}{ Future } \\
\hline $\begin{array}{l}\text { Relationship between productivity } \\
\text { enhancement of employees and } \\
\text { research and innovation }\end{array}$ & No linkage & $\begin{array}{l}\text { Linkage within the same National } \\
\text { Research and Innovation Policy } \\
\text { Council }\end{array}$ \\
\hline Policy determination & Not explicit & N/A \\
\hline $\begin{array}{l}\text { Research grants } \\
\text { Distributed to too many organiza- } \\
\text { tions ignored on social science and } \\
\text { humanities }\end{array}$ & $\begin{array}{l}\text { Primary funded by National Re- } \\
\text { search Council of Thailand }\end{array}$ \\
\hline $\begin{array}{l}\text { Relationship resources (such as } \\
\text { graduates, researches, etc.) }\end{array}$ & No linkage \\
\hline $\begin{array}{l}\text { Information on higher education, } \\
\text { science, research and innovation }\end{array}$ & Distributed, incomplete & $\begin{array}{l}\text { Response the needs of people } \\
\text { connection }\end{array}$ \\
\hline
\end{tabular}

These include the revolutions of Industry 4.0 and Thailand 4.0, 2030 Agenda for the United Nations Sustainable Development Goal 4 (SDG 4) in Quality Education, ASEAN Economic Community (AEC) preparations, workforce's need, middleincome gap, population aging, deterioration of natural resources due to unsustainable economic growth, and educational quality and management system development [2]. Among these issues, the primary challenges are a middle-income trap, an inequality trap, and an imbalanced trap [16]. However, the $21^{\text {st }}$ century's intellectually intensive on jobs opportunity has changed by the industrial revolution. Education 4.0 is promoted to stimulate learners to be creative and innovative. The life skills or the innovative skills to live in the era of Education 4.0, besides possessing $21^{\text {st }}$ century skills, consist of leadership, collaboration, creative, digital literacy, effective communication, emotional intelligence, entrepreneurship, global citizen, problem-solving and teamwork. It also has to include the skills of building an intelligent nation or intelligent people who are with critical thinking, creativity, innovation, cross-cultural understanding, information and media literacy, career and learning skills [13].

\section{Conclusion}

The research conducted documentary research method to support the viewpoint of the challenges and future trends toward Industry Revolution 4.0, Thailand 4.0, and Education 4.0 themes. The authors identified three similar agendas after a careful analysis of previously conducted studies. It can conclude that there is a vibrant interconnection among the three agendas, and all are mutually interdependent and adapted in many countries to augment individual and institutional growth. 


\section{References}

[1] The Ministry of Education, "The Basic Education Core Curriculum B.E. 2551 (A.D. 2008)”, 2008. [Online]. Available: http://www.act.ac.th/document/1741.pdf. [Accessed: Mar. 11, 2019].

[2] The Office of the Education Council, "National Scheme of Education," (n.d.). [Online]. Available: www.onec.go.th/us.php/home/category/CAT0001145. [Accessed: Mar. 11, 2019].

[3] Office of the Education Council, Education in Thailand. Bangkok: Prigwan Graphic Co., Ltd., 2017.

[4] The Office of the Higher Education Commission, "Thai Education System," (n.d.). [Online]. Available: http://inter.mua.go.th/education-system/. [Accessed: Feb. 25, 2019].

[5] The Medical Council of Thailand, "The Medical Council of Thailand's Announcement," 2009. [Online]. Available: https://www.tmc.or.th/service law03 14.php. [Accessed: Feb. 20, 2019].

[6] Foreign Consultants, "Education System of Thailand," 2005. [Online]. Available: https://www.foreignconsultants.com/thailand-educ.php. [Accessed: Feb. 20, 2019].

[7] "Industrial Revolution | Definition, Facts, \& Summary," Encyclopedia Britannica, n.d. [Online]. Available: https://www.britannica.com/event/Industrial-Revolution. [Accessed: Mar. 11, 2019].

[8] The Royal College of Physicians of Thailand, "Awarding Medical Diploma of the Thai (subspecialty) Board Equivalent to $\mathrm{PhD}$ Equivalent", 2012. [Online]. Available: http://www.rcpt.org/index.php/rcptnetwork/2012-10-04-06-11-19/544--qq.html. [Accessed: Mar. 11, 2019].

[9] J. Scott, Documentary Research (SAGE Benchmarks in Social Research Methods). SAGE Publications Ltd., 2006.

[10] P. Jones, R. Stowell, J. Namchaisiri, and P. Sethakul, "New Manufacturing Technicians Responding to Industry 4.0," Chevron Enjoy Science, n.d.

[11] S. Wittayasin, "Education Challenges to Thailand 4.0," Int. J. Integr. Educ. Dev, vol. 2, no. 2, p. 29-35, December, 2017.

[12] "Model 'Thailand 4.0' Thailand innovation-driven," Jan 21, 2017. [Online]. Available: https://www.mmthailand.com. [Accessed: Mar 11, 2019].

[13] V. Puncreobutr, "Education 4.0: New Challenge of Learning," St. Theresa Journal of Humanities and Social Sciences, vol. 2, no. 2, p. 92-97, December, 2016.

[14] Ernst \& Young LLP, "Leapfrogging to Education 4.0: Student at the core," 2017. [Online]. Available: https://www.ey.com/Publication/vwLUAssets/ey-leap-forgging/\$File/ey-leapforgging.pdf. [Accessed: Mar. 12, 2019].

[15] "Cabinet approves new education, innovation ministry proposal," Thai PBS World, 2018. [Online]. Available: https://www.thaipbsworld.com/cabinet-approves-new-educationinnovation-ministry-proposal/. [Accessed: Mar 12, 2019].

[16] Royal Thai Embassy Washington D.C., "Thailand 4.0,", n.d. [Online]. Available: https://thaiembdc.org/thailand-4-0-2/. [Accessed: Mar 11, 2019].

\section{$7 \quad$ Authors}

Dr. Panarit Sethakul, an assistant Professor was IEEE Education Society Chapter Chair, IEEE Thailand Section and works as International Conference Chair (IC- 
TechEd, TALE, IIW-IC). Currently, he is an Advisory to Dean of Faculty of Technical Education, Chairman of the Association of Industrial Education of Thailand (AIET). He is the Chief Executive Officer of Welding Institute of Thailand (IIW ANB-Thailand), Chairperson of Committee for Development of Assessment Systems for Vocation Education (ONESQA), and a member of sub-committee of Education Standard, Office of Higher Education Commission (OHEC), Ministry of Education.

Dr. Nattakant Utakrit is an Assistant Professor, lecturer and researcher at the Department of Technical Education Management, Faculty of Technical Education. Nattakant received the 2018 outstanding young researcher in social science, and has a number of research publications in various disciplines. Her research interests include digital forensics, information security and intelligence, innovation in education and technology, and applied statistics in information technology.

Article submitted 2019-01-28. Resubmitted 2019-03-12. Final acceptance 2019-03-13. Final version published as submitted by the authors. 